\title{
SUSTAINABILITY OF INDONESIA TRADEMARK LAW AS UMBRELLA LAW IN RESOLVING DOMAIN NAMES DISPUTE IN INDONESIA
}

\author{
Ayup Suran Ningsih* \\ Faculty of Law, Universitas Negeri Semarang \\ Sekaran, Gunungpati, Semarang City, Central Java 50229
}

\begin{abstract}
Protection regarding intellectual property in domain names becomes an important thing that must be considered by the domain name's holder or user. Domain names are by character quite similar to trademarks since they serve as source indicators. This article is written to analyse the Suitability of Indonesia Trademarks Law as Umbrella Law in Resolving Domain Names Dispute in Indonesia. The methodology used in writing this article is normative legal research. Through the comprehensive discussion, it can be concluded that Indonesia trademark law is not suitable to resolve domain name dispute in Indonesia. A domain name is different from a mark based on Indonesia Trademark Law.
\end{abstract}

Keywords: domain name, trademark, mark, sign, dispute.

\section{Intisari}

Perlindungan terkait kekayaan intelektual dalam nama domain menjadi hal penting yang harus dipertimbangkan oleh pemegang atau pengguna nama domain. Nama domain secara karakter sangat mirip dengan merek dagang karena mereka berfungsi sebagai indikator sumber. Artikel ini bertujuan untuk menganalisis Kesesuaian Hukum Merek Dagang Indonesia sebagai Hukum Payung dalam Menyelesaikan Sengketa Nama Domain di Indonesia. Metodologi yang digunakan dalam penulisan artikel ini adalah penelitian hukum normatif. Melalui pembahasan yang komprehensif dapat disimpulkan bahwa hukum merek dagang Indonesia tidak cocok untuk menyelesaikan perselisihan nama domain di Indonesia. Nama domain berbeda dengan tanda yang diatur pada UU Merek Dagang Indonesia.

Kata Kunci: nama domain, merek dagang, tanda, sengketa.

\section{Pokok Muatan}

A. Introduction 194

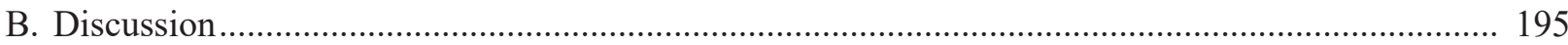

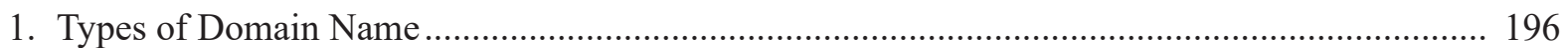

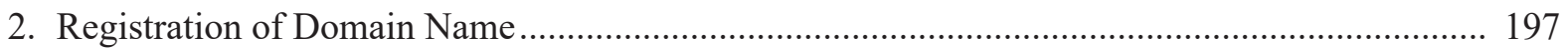

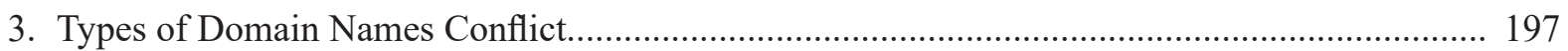

4. Pengelola Nama Domain Internet Indonesia (PANDI) _............................................................. 198

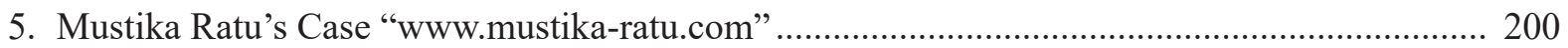

6. Analysis The Relation between Domain Name and Trademark Based on Indonesian

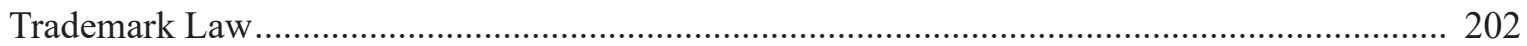

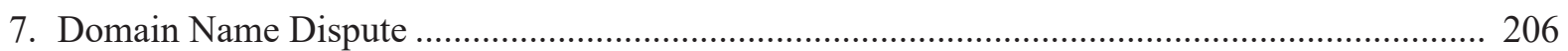

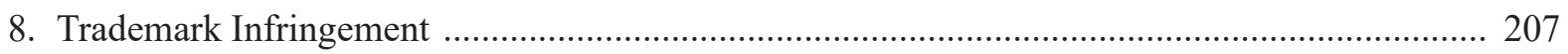

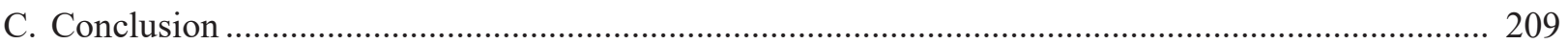

Correspondent email address: ayuupp@mail.unnes.ac.id 


\section{A. Introduction}

The Internet is not something exclusive again today. Everyone uses the Internet to connect with their friends, colleagues, and even with their customers worldwide. The Internet has broken down the boundaries of space and time. The Internet makes it easier to interact with anyone at any time. One part of the Internet, which is the concern of this paper, is the domain name. With the development of the Internet and to survive in business competition, Entrepreneurs realise the importance of this Internet. ${ }^{1}$ Entrepreneurs who initially do with conventional transactions now use the Internet as a medium to market their products. Transactions are initially conventional. After the Internet's development, it transformed transactions into electronic, from the stage of Searching, Ordering and Payment, and Delivery, known as E-commerce. ${ }^{2}$

Nowadays, Digital Industry in Indonesia is developing so fast. It can be seen with so many people make transactions digitally, or as we called it online. One of the main parts in the digital industry is the Domain Names, the more popular, the more expensive.

One of the legal problems faced by many companies in the world is the existence of the domain name. Domain name was originally just a name addresses on the Internet, eventually become a place for promotion and selling of products and information. Many Entrepreneurs have trademarks, company names, or product names that have been registered online have similar domain names of famous domain names. Of course, it was such a loss for the original or the first registered domain names. The data show that PPND, as a non-litigation institution in domain name's dispute, decided 18 cases since was born in Indonesia. ${ }^{3}$ It shows that they feel something wrong and unfair in using the domain name.

Of all the technological discoveries that ultimately shaped the Internet, domain names can be said to be the ones that have had the most significant impact on the global business world. These considerations also led VeriSign Inc., a network security company, in 2000 to buy NSI for USD 21 billion. Such a large sum is comparable to NSI's strategic value in a global Internet-based economy as a monopoly on the registration and management of domain names under .com, .net, and .org, making up the largest population on the Internet. Even though VeriSign is a giant company in Internet business, its grip on this business is still incomplete if it has not mastered the domain name business. ${ }^{4}$ That fact shows that domain name has such a tremendous economic value, so if there is such infringement in the domain name, it should be judged in the right way and used the proper law. It is the author's primary concern in writing this article.

The similarity of the domain names can make costumer confuse, it can lead costumers to choose the wrong product, and it is a loss for the original or the first domain name. This condition can lead to domain name legal dispute, both of the domain name's owner will say that they are right. So, the law must have a decision on which one is the right one. Because of that concern, the author focused on analysing the Suitability of Indonesia Trademarks Law as Umbrella Law in Resolving Domain Names Dispute in Indonesia.

A domain name may be protected as a trademark is used in commerce to indicate the source or origin of goods or services. In the case of services, the mark must be displayed in the sale or advertising of services. ${ }^{5}$ The registration of domain names on the Internet has become a growing concern

\footnotetext{
Ayup Suran Ningsih, "Implikasi Undang-Undang Nomor 5 Tahun 1999 tentang Larangan Praktek Monopoli dan Persaingan Usaha Tidak Sehat pada Pelaku Usaha Mikro Kecil dan Menengah (UMKM).” Jurnal Penelitian Hukum De Jure 19, No. 2, 2019 , pp. $207-215$.

Paustinus Siburian, Arbitrase Online, Djambatan, Jakarta, 2004, p. 2.

Penyelesaian Perselisihan Nama Domain, "Putusan", https://ppnd.pandi.id/putusan/ accessed on 10th August 2020.

Kementerian Hukum dan HAM RI, "Konstruksi Hukum Nama Domain: Sebuah Kepemilikan Atau Lisensi”, http://ditjenpp.kemenkumham.go.id/ hukum-teknologi/669-konstruksi-hukum-nama-domain-sebuah-kepemilikan-atau-lisensi.html accessed on10th August 2020.

Thomas J Smedinghoff, 2000, Online Law TheSPA's Legal Guide to doing Business on The Internet, Addison Wisley, Boston, p. 232.
} 
when those names are potential trademarks. ${ }^{6}$

An easily remembered domain name is closely connected with the company's name, or trademark is valuable in that users van readily locate, and thus visit the site. Therefore, a domain name can function as a trademark in that it may identify a particular source and quality of goods or services on the Internet. This connection between domain names and trademarks has led to many disputes between trademark and domain name holders. ${ }^{7}$ For the information and reference, Trademarks Law has been used to resolve domain name disputes in the United Kingdom and Australia. The aim of writing this article is to give a legal review regarding domain name dispute and to analyse the Suitability of Indonesia Trademarks Law as Umbrella Law in Resolving Domain Names Dispute in Indonesia. The methodology used in writing this article is the normative legal research method. This method emphasises secondary data. ${ }^{8}$ Secondary data in this study is divided into primary legal materials (binding legal regulations), secondary legal materials, and tertiary legal materials related to domain names, trademarks, and internet disputes. The legal materials are collected through literature study, which then being analysed qualitatively to obtain correct conclusions.

\section{B. Discussion}

Domain names are the human-friendly forms of Internet addresses and are commonly used to find web sites. A domain name also forms the basis of other methods or applications on the Internet, such as file transfer or email addresses. ${ }^{9}$ For example is www.ukm.my or www.undip.ac.id . A domain name is human-friendly forms from internet protocol (IP) numbers. ${ }^{10}$ Every computer connected to the Internet has a unique Internet Protocol ("IP') address. Each domain name is unique and thus can only be registered to one entity. A domain name is created when it is registered with the appropriate registry operator. A registry operator maintains the definitive database, or registry, that associates the registered domain names with the correct IP numbers for the respective domain name servers. ${ }^{11}$

Internet protocol is a unique numerical identifier (numbers) used to connect the Internet and connected computers. For example, 132.54.321.89. It will be tough to memorise all of those numbers if we want to access some of the websites. Hence, to make it easier for humans, a system called domain name is created with alphabetical. The Domain Name System is essentially a global addressing system. It is the way that domain names are located and translated into Internet Protocol (IP) addresses. $^{12}$

There are two parties in domain names management. They are registrant and registrar. Registrant is a domain name holder, and registrar is a company that accepts applications for and register domain names. Furthermore, the registry is the central directory. The registry is the authoritative database for each level of domain. ${ }^{13}$ For Indonesia, the registry is PANDI (Pengelola Nama Domain Indonesia). The registry operator is responsible for maintaining the ccTLD Registry and ensuring the domain name system's integrity and stability.

Indonesian Law also has a regulation that

\footnotetext{
Kenneth Creech, 2000, Electronic Media Law and Regulation Third edition, Butterworth-Heinemann, Oxford, p. 198.

Dennis Cambell and Christian Champbell, 1998, Law of International Online Business A Global Perspective, Sweet \& Maxwell, London, p. 671.

Ayup Suran Ningsih, "License Revocation of Insurance Companies and Legal Protections of the Policyholders", Jurnal Hukum Novelty, 11(1), 2020, pp. 95-104.

World Intellectual Property Organization, "Frequently Asked Question: Internet Domain Names, http://www.wipo.int/amc/en/center/faq/ domains.html, accessed on 20th April 2019.

Chris Reed, 2004, Internet law: text and materials, Cambridge University Press, Cambridge, p. 134

The United States Court of Appeals, 2010, 9th Circuit, Office Depot Inc v Zuccarini.

World Intellectual Property Organization, Loc. cit.

Brian Fitzgerald, Anne Fitzgerald, et.al, 2011, Internet and E-commerce Law, Business and Policy, Thomson Reuters (Professional), Sydney, p. 623.
} 
explains the definition of a domain name. It is Law of Republic Indonesia Number 11 of 2008 concerning Electronic Information and Transaction. The definition of a domain name, as explained in Article 1 paragraph 20,“domain name means an internet address of a state administrator, person, business entity, and/or the public that can be used for communication over the internet in the form of unique character code or set to identify a certain location on the internet."

This act also defines the principle when registering a domain name. Article 23(1) explains that when registering a domain name, the principle applied is "first come first served." In elucidation of this section explains that domain name shall be addresses or identity of state administrator, persons, business entities, and/or the public obtained on a first applicant principle in domain name policy is different from one in the field of intellectual property rights in that no substantive examination is required while it is in the registration of Trademarks and Patents.

This act also concerns regarding intellectual property rights. Article 23(2) explains that holding and using domain names must be based on good faith, non-violation of fair business competition ${ }^{14}$, and non-infringement of other persons' rights. Hence, domain names' protection regarding intellectual property rights becomes an important thing that must be considered by the domain name's holder or user. Section 3 mentions that holding or using a domain name damaged by another person's unauthorised use of domain names shall be entitled to lodge a claim for cancelling such domain names. Besides this act Law of Republic Indonesia Number 11 of 2008 concerning Electronic Information and Transaction, regulation concerning domain name was also enacted in the Regulation of the Minister Communications and Information Republic of Indonesia number 23 of 2013 regarding Domain Name Management. Furthermore, regarding the infringement of well-known marks in the domain name, this paper will discuss the suitability of using Indonesia's trademark law to resolve domain name disputes.

\section{Types of Domain Name}

A domain name consists of two or more strings of characters "labels" separated by dots. For example, in the domain name "unnes.ac.id," the label at the far right-hand side (.id) is the top-level domain, the label second from the right (.ac) is the second-level domain, while the label third from the right (unnes) is the third level domain. ${ }^{15}$ There are two broad categories of top-level domains (TLDs): ${ }^{16}$

a. Generic top level domains (gTLDs)

Generic top-level domains (gTLDs) were created for use by the internet public and fall into three main categories: open, sponsored, and restricted. For example are .com, .org, .net, .int, .gov, .edu, .mil . Internet Corporation for Assigned Names and Number (ICANN) has delegated control over each of the gTLDs to a domain name registry. Domain names may be registered in the open and sponsored gTLDs through one of the many ICANN-accredited registrars. ${ }^{17}$ b. Country code top level domains (ccTLDs)

Country code Top Level Domain (ccTLDs) were created as individual domains for countries. There are almost 270 ccTLDs $^{18}$, consisting of two letters corresponding to the name of a country, territory, or other

\footnotetext{
Ayup Suran Ningsih, 2019, Hukum Persaingan Usaha dan Geliat UMKM, Fastindo, Semarang, p. 78.

Brian Fitzgerald, Anne Fitzgerald, et.al, Op. cit., p. 604.

Ibid, pp. 623-631.

See the list of accepted registrar at Internet Corporation for Assigned Names and Numbers, "Registry Listings", http://www.icann.org/en/ resources/registries/listing, accessed on 28th April 2018.

18 See the list of accepted ccTLDs at Internet Assigned Numbers Authority, "Root Zone Database", http://www.iana.org/domains/root/db, accessed on 28th April 2018.
} 
geographic location. For example are au (Australia), .aq (Antarctica), .ca (Canada), .co (Colombia), .cn (China). The ccTLDs for Indonesia is .id . each national administrator operates the ccTLD according to practices, procedures, and policies developed in the context of the country's economic, cultural, linguistic, and legal circumstances.

\section{Registration of Domain Name}

A feature of the domain name system is that domain names are registered on a first-come, firstserved basis. Subject to the relevant eligibility and allocation rules being satisfied, the first registrant to apply for a particular domain name is entitled to hold the license for it.

There is no hierarchy of rights to register a domain name. Domain names are registered in the open generic TLDs by applying to one of the ICANN-accredited registrars. ICANN stands for Internet Corporation for Assigned Names and Number, an internationally organised, non-profit corporation with its headquarters in California, established a private-public structure for the governance of the Domain Names System (DNS). In reality, the United States government retained ultimate authority. ${ }^{19}$

The domain name proposed by the registrant is checked against an online database and, if another registrant has not already registered it, will normally be immediately allocated to the applicant. Domain names are typically registered online through the registrar's website. ${ }^{20}$

Information about domain name registrations held in the gTLD registries and many ccTLD registries can be obtained through the WHOIS database provided by most domain name registries.
A WHOIS service enables members of the public to search an openly accessible database of information on domain names to find out the technical, administrative, and contract details of a domain name registrant so that technical, legal, and other matters relating to the registration and use of the domain name can be promptly resolved. WHOIS is not an acronym. It is from the question, who is responsible for a domain name or an IP address. Anyone can use the WHOIS protocol to search their databases and identify the registered name holder or "registrant" of a domain name. ${ }^{21}$ PANDI also has a WHOIS database. ${ }^{22}$

The policy of open access to registrants' information is reflected in ICANN's contracts with registrars and registrar practices. In the Registrar Accreditation Agreements (RAAs) between ICANN and accredited gTLD registrars, each registrar is required to provide an interactive webpage and a port WHOIS service which enables free, public, query-based access to up-to-date data about all active registered domain names sponsored by the registrar for each TLD for which it is accredited. ${ }^{23}$

\section{Types of Domain Names Conflict}

a. Competing claims of legitimate trademark owners

Suppose different persons have registered the same trademark in respect of different categories of goods and/or services or where different persons register a trademark in each jurisdiction. In that case, a conflict may arise regarding which of the registered trademark owners is entitled to register the domain name.

b. Infringement of registered Trademark Where a domain name registrant

Internet Corporation for Assigned Names and Numbers, http://www.icann.org/, accessed on 1st May 2018.

Internet Corporation for Assigned Names and Numbers, "Domain Name Registration Process", http://whois.icann.org/en/domain-nameregistration-process, accessed on 1st May 2018.

Internet Corporation for Assigned Names and Numbers, “About WHOIS”, http://whois.icann.org/en/about-whois, accessed on 1st May 2018. PANDI, https://pandi.id/whois/, accessed on 28th September 2020.

Internet Corporation for Assigned Names and Numbers, "Information for Registrars", http://www.icann.org/en/resources/registrars, accessed on 1 st May 2018. 
establishes a website, using a domain name that is identical with, or substantially similar to, a registered trademark concerning the same or similar goods and/or services as those for which the trademark is registered, use of the domain name may infringe the registered trademark.

c. Cybersquatting (cyberpiracy or domain name piracy)

This practice involves bad faith, abusive registration, and use of others' distinctive trademarks as domain names to obtain an advantage from the goodwill associated with those trademarks, typically by offering the domain name for sale at a substantial profit.

\section{d. Typosquatting}

This practice involves the registration of deliberately misspelt variants of popular domain names in order to divert trade or traffic, often with the assistance of software that shows the most common typographical errors or misspellings of a domain name.

\section{e. Meta tagging}

This practice involves using codes (metatags) in the source code of the pages of a website which contain keywords or descriptions referring to the names or trademarks of competitors so that when users search the Internet for those names or trademarks, the metatags bring up the website or page in which the metatags has been included.

f. Reverse domain name hijacking

This practice involves a trademark owner bringing a complaint under the UDRP (Uniform Domain Name Dispute Resolution Policy) against a domain name registrant "in bad faith in an attempt to deprive a registered domain name holder of a domain name"

\section{Pengelola Nama Domain Internet Indonesia (PANDI)}

Indonesian Internet Domain Name Registry
(PANDI) is an Indonesian Top-Level Domain Name Registry (.ID) assigned by the Minister of Communication and Information Technology (Kominfo) of the Republic of Indonesia with Decree No. 806 of 2014.

PANDI is a non-profit organisation formed on December 29, 2006, by the Republic of Indonesia and the Indonesian internet community. PANDI is formed to manage the domain name .ID professionally, accountably, and transparently in accordance with the regulations of the Republic of Indonesia.

On June 29 2007, through the Ministry of Communication and Information Technology Indonesia, the government officially gave the domain's administration to PANDI. The delegation is written in the Record of Domain .id Administration Assignment no. BA-343 / DJAT / MKOMINFO / 6/2007 from Directorate General of Aptel.

PANDI is a legal entity, consists of individuals from the Indonesian internet multi-stakeholders. PANDI membership reflects the representation of the government of the Republic of Indonesia, academics, and business people.

To run the domain name registry .ID, every four years, the members of PANDI choose the PANDI Executive Council through a Members General Meeting. The Executive Council, therefore, chooses the Chairman of PANDI, who also acts as the President Director of PANDI. The Executive Council also assigns the other directors in the Board of Directors, as proposed by the President Director. Board of Directors are professionals who work full time in PANDI.

PANDI is supported by capable and dedicated staff who always develop themselves to adhere to the changes and technological evolution in the community of internet users - in Indonesia and internationally.

To organise more details regarding domain name management, The Minister Of Communications And the Information Republic of Indonesia enacted The Regulation Of The Minister Communications And the Information Republic Of 
Indonesia Number 23 Of 2013 Regarding Domain Name Management and The Regulation Of The Minister Communications And the Information Republic Of Indonesia Number 5 of 2015 regarding Registrar Government Institution Domain Name. This act covers all about domain name management. This act defines the rule to register, use, and resolve a domain name's dispute.

There are so many id domains that are already registered by PANDI. PANDI provides the latest data regarding the registered domain names in 2019 in March.

Table 1.

Registered Domain Names in 2019 In March

\begin{tabular}{lll}
\hline No & \multicolumn{1}{c}{ Domain Name } & \multicolumn{1}{c}{$\begin{array}{c}\text { Number of } \\
\text { Registered in } \\
\text { March 2019 }\end{array}$} \\
\hline 1 & ac.id & 4,834 \\
\hline 2 & biz.id & 2,074 \\
\hline 3 & co.id & 109,868 \\
\hline 4 & desa.id & 8,045 \\
\hline 5 & go.id & 4,069 \\
\hline 6 & id & 107,263 \\
\hline 7 & mil.id & 350 \\
\hline 8 & my.id & 6,373 \\
\hline 9 & net.id & 470 \\
\hline 10 & or.id & 9,409 \\
\hline 11 & sch.id & 21,327 \\
\hline 12 & web.id & 31,712 \\
\hline 13 & ponpes.id & 300 \\
\hline 14 & Reservasi Kominfo & 0 \\
\hline & Total & 306,094 \\
\hline
\end{tabular}

Source: Pandi, $2019^{24}$

The companies or organisations that accept the registration of a domain name. PANDI must accredit the registrar for the Indonesian domain name as the registry in Indonesia. PANDI separates the registry function and the registrar function.
As the registry of domain .id, PANDI focuses on managing all the technical resources and networks, and most important part, the Policy Development.

PANDI carries out its registrar function by organising registration services. It chooses the registrar company through stages of the selection process until the company is accredited as a PANDI's registrar.

Currently, PANDI has 23 registrars ${ }^{25}$, and the whole registration system is integrated into PANDI's registry system using the Shared Registry System and Standard EPP Protocol. PANDI and the 12 registrars are now in the front line as one unified Domain Name Registration Services.

The general requirement for registering domain names in PANDI are: ${ }^{26}$

a. The Applicant must provide correct, accurate, and complete information.

b. The Applicant must provide the Applicant's Full Name.

c. The Applicant must include the name of the Applicant's Business Entity.

d. The Applicant must include the domicile in accordance with the identity card or the Certificate of Domicile.

e. The Applicant must attach the Tax Identification Number.

f. The Applicant must include the Brand Certification or attach the trade names they want to use, copy of the Deed of Company Establishment, the Validity Letter from Ministry of Law and Human Rights, copy of SIUP, copy of Tax Identification Number, copy of Certificate of Domicile.

g. The Applicant must enclose the correspondence address of the Applicant. This address will be used for correspondence.

h. The Applicant must attach a phone number and email address where the Applicant can be contacted for the purpose of communication. 
i. The Applicant must specify the server address and a permanent address that can be visited by PANDI for accreditation purposes.

j. The Applicant must state the full name, contact information, and position of all the directors, managers, and employees and ensure that PANDI can investigate the people listed.

k. The Applicant is not in the process of civil lawsuits or bankruptcy that may result in the Applicant's business cessation.

1. The Applicant or the Applicant's business entity is not included in the blacklist of government contractors.

m. The Applicant or others mentioned in the application should not have any affiliation with other PANDI's accredited Registrars, and the Board of Directors or employees of PANDI.

n. The Applicant must have a business domain URL with the Indonesian Second Level Domain/Top Level Domain (DTD/DTT).

o. If there are any changes in the application's information, the Applicant shall notify PANDI in writing as soon as possible.

p. The Applicant must demonstrate and ensure that the Applicant has the capabilities and has the legal authority to:

1) complete and submit the registration;

2) make the whole disclosure, give permit, and fulfil the obligations written in these terms and conditions; and

3) Involve in the Registrar Accreditation Agreement with PANDI if the application is accepted.

q. The Applicant understands that PANDI does not accept the submission made for a private individual or an individual's business entity, PANDI will reject the application made by private individuals without any refund.

r. Registrar accreditation application must be submitted in the format specified by PANDI and set in PANDI's Policy. s. The Applicant acknowledges that PANDI must comply with all laws and regulations in the Republic of Indonesia.

t. Applicant must fully cooperate with PANDI during the period of examination by PANDI and give PANDI access to employees and shareholders, documents, and records relevant to the accreditation process.

1) The domain names must match the naming criteria.

2) Domain names must respect and not contrary to intellectual property rights, patents, trademarks. For co.id and net.id if the requirements SIUP/TDP (Surat Ijin Usaha Perdagangan/ Tanda Daftar Perusahaan) (company's license), deeds, tax ID, and others are in the process of manufacture, must be attached a statement/statement from a notary.

3) If deemed necessary, Internet Domain Name Indonesia (PANDI) may request such clarification statement/ description/explanation (look up article 23(2) Law of Republic Indonesia Number 11 of 2008 concerning Electronic Information and Transaction).

4) The validity of a domain is one or two years from the date of approval of the domain name's use.

\section{Mustika Ratu's Case "www.mustika-ratu. com"}

Today, many people are doing an infringement in trademarks, especially for the well-known mark, they make similar domain names with the famous or well-known mark. One of kind of infringement in a well-known mark is domain names' infringement. The first well-known mark's infringement in domain name in Indonesia is the case of the domain name "mustika-ratu.com". The party of this case are between Mustika Ratu (cosmetic company) and Tjandra Sugiono. This case got much attention in 
Indonesia because it was the first case on domain name.

The chronology of this case is:

a. On September 1999 Tjandra Sugiono became General Marketing International in Martina Berto (herbal cosmetic company)

b. On October 71999 Tjandra Sugiono has registering the domain name of Mustika-ratu.com in Network Solution. Then on June 162000 Tjandra Sugiono resigned from Martina Berto. (when Tjandra Sugiono registered the domain name he still Martina Berto's employee)

c. On July 2000 Mustika Ratu (also herbal cosmetic company) want to register his domain name in Network Solution but he can not register his domain name because mustika ratu's domain name has registered by Tjandra Sugiono. Knowing that his trademark has been registered by another company, Mustika Ratu feel angry and aggrieved. Then on August 29 till September 12001 Mustika Ratu has published complaint on some of mass media and requested for the cancellation of the Mustika-ratu.com from Tjandra Sugiono.

d. On September 42000 Mustika Ratu reported this case to police. Then on September 282000 Network Solution has canceled the domain name of Mustika-ratu.com. This cancellation was not become the end of this case because Mustika Ratu still continue his complaint to Tjandra Sugiono because Mustika Ratu felt that he has loss until 10 billion rupiah. Mustika ratu claimed that the domain name that was registered by Tjandra Sugiono was confusingly similar to his registered domain name www.mustikaratu.co.id.

e. At that time Tjandra Sugiono has charged based on article 382 bis of Penal Code.

"Any person who, in order to establish, to retain, or to expand the sale of his trade or business, or those of the trade or business of another, commits fraudulent act of misleading the public or a certain person, shall, if some loss from competitors or competitors of the other person may arise, being guilty of unfair competition and be punished by a maximum imprisonment of one year and four months or a maximum fine of nine hundred rupiahs."

Tjandra Sugiono, as an employee of Martina Berto, has registered the well-known mark domain name without permission from the mark's owner. It is indicated that there is unfair competition. It is one of the infringements of article 19 (b) Law of Republic Indonesia Number 5 of 1999 concerning Indonesia Anti-Monopoly And Unfair Business Competition.

Entrepreneurs are prohibited from conducting one or more activities, either separately or jointly with other entrepreneurs, which can cause monopolistic practices and/or unfair business competition by:

a. refusing and/or hampering certain entrepreneurs from conducting the same type of business in the relevant market;

b. hampering the consumers or clients of their company's competitors from conducting any business contact with those company's competitors; or

c. restricting distribution and/or selling of the goods and/or services in the relevant market; or

d. conducting discrimination practices against certain entrepreneurs.

Because of the infringement of article 19 (b) Tjandra Sugiono can be charged with the criminal provision from article 48 (1) : 
(1) Violations to the provisions in Article 4, Articles 9 through 14, Articles 16 through 19, Article 25, Article 27 and Article 28 of this law is subject a criminal fine in the amount of at least $R p .25,000,000,000$ (twenty five billion rupiahs) and in the amount of $R p$. 100,000,000,000 (one hundred billion rupiahs) at the most, or imprisonment at a maximum period of 6 (six) months

www.mustika-ratu.com case was the first case on domain name, but at that time, the judges were not using trademark law to resolve the dispute. The judges were using the Penal Code and Law of Republic Indonesia Number 5 of 1999 concerning The Ban On Monopolistic Practices And Unfair Business Competition. The author will explain the reason regarding this decision in the next part.

As noted, before, in practice the judiciary in Indonesia, only 1 (one) case reached court proceedings, which is the domain name of mustikaratu.com case. As already been explained before, the case has resolved with lex generalis, Penal Code and Law of Republic Indonesia Number 5 of 1999 concerning The Ban on Monopolistic Practices And Unfair Business Competition. At that time, that case was not resolved with lex specialis (trademark law) like in some countries like United State and Austria. Hence, the settlement mechanism is based on the Criminal Procedure Code.

\section{Analysis The Relation between Domain Name and Trademark Based on Indonesian Trademark Law}

Indonesia is one of the members of the Trade-Related Aspects of Intellectual Property Rights (TRIPS). ${ }^{27}$ TRIPS is the umbrella rule for Intellectual Property Rights rule for their member. The intellectual property rights rule in each member country must be appropriate with TRIPS. ${ }^{28}$ As already explained before Indonesia trademark law has been amended three times. The first trademark law is Law Number 19 of 1992. In 1997 has been amended with Law Number 14 of 1997 regarding Trademark, and in 2016 Indonesia has new Trademark Law. Today, Law of Republic Indonesia Number 20 of 2016 regarding Trademark and Geographic Indication is entered into force.

To explain the suitability of using trademark law to resolve domain name dispute in Indonesia, firstly the author would like to explain about the definition of trademark in TRIPS and the three law of trademark in Indonesia. The definition of mark and trademark is important because the definition explains the scope of the protectability of subject matter. Indonesian trademark Law makes a different definition between mark and trademark. Furthermore, the author would like to explain the change of the definition of trademark in Indonesian trademark law to give the historically and comprehensive view.

Ningsih, Ayup Suran, and Balqis Hediyati Maharani. "Penegakan Hukum Hak Cipta Terhadap Pembajakan Film Secara Daring." MetaYuridis 2.1 (2019).

28 Ningsih, Ayup Suran, Waspiah Waspiah, and Selfira Salsabilla. "Indikasi Geografis atas Carica Dieng sebagai Strategi Penguatan Ekonomi Daerah." Jurnal Suara Hukum 1.1 (2019): 105-120. 
Table 2.

Historical definition of Trademark in Indonesian Trademark law

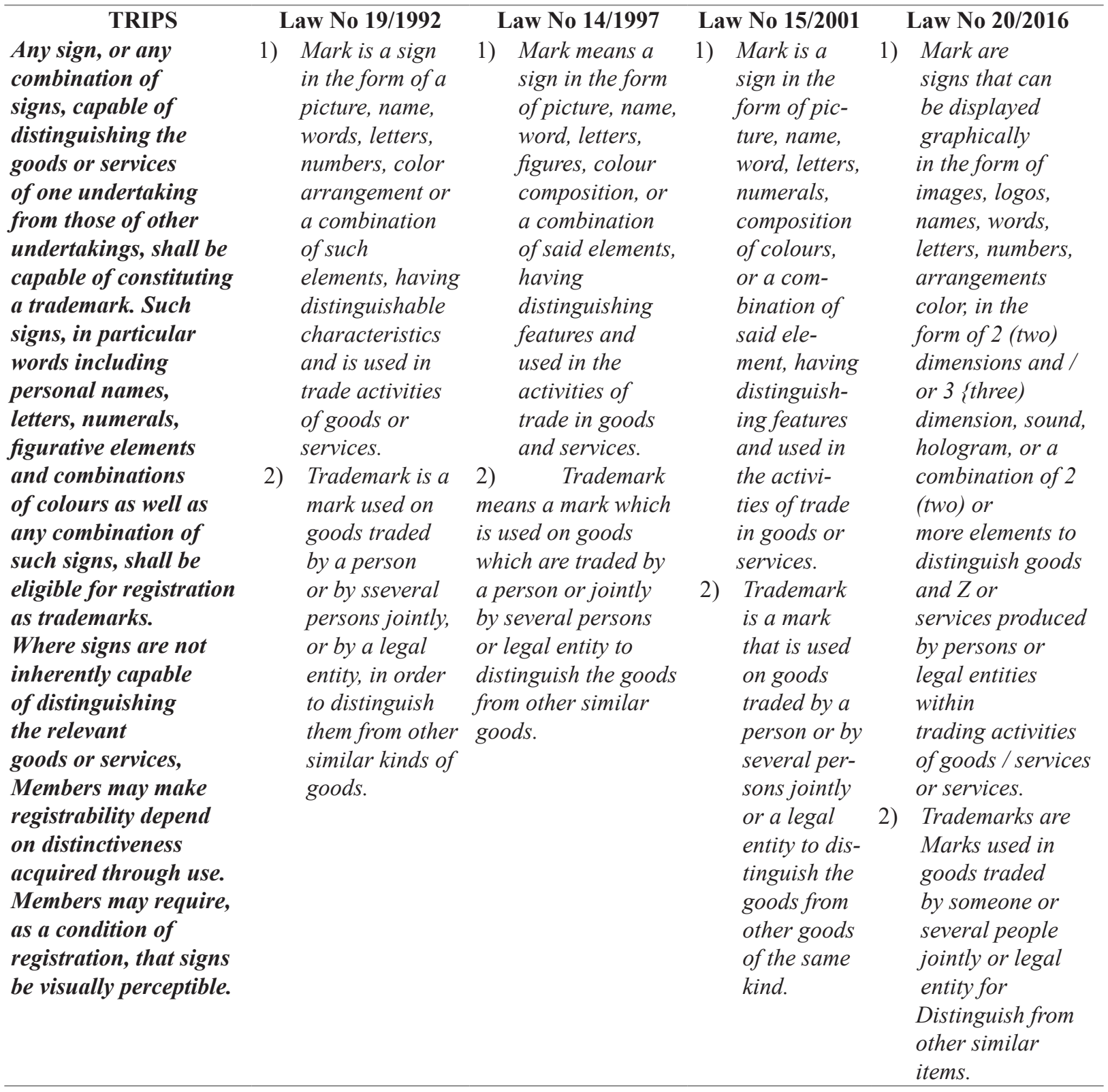

Source: Processed by the author, 2020

Overall, there are no significant differences regarding the definition of mark and trademark in the fourth Indonesian Trademark Law. Hence, the author has explained before that based on Indonesian Trademark Law. There is a difference between mark and trademark in the definition. In Indonesian trademark law, mark means sign. In the following part, the author would like to explain the differences between mark and domain name: 
Table 3.

\section{Differences Between Mark And Domain Name}

\begin{tabular}{ll}
\multicolumn{1}{c}{ Domain name } \\
$\begin{array}{ll}\text { Domain name is not proprietary right. Therefore, the } \\
\text { owner of domain name still can be sued. }\end{array}$ & $\begin{array}{l}\text { Mark } \\
\text { After the mark has been registered, the owner of the mark } \\
\text { will get legal protection. }\end{array}$ \\
$\begin{array}{l}\text { Domain name is very unique, and there is only one } \\
\text { for each domain name in the world. }\end{array}$ & $\begin{array}{l}\text { For mark, the same mark can be owned by two different } \\
\text { people, as long as the mark is in a different class of goods } \\
\text { or class of service or from a different country. }\end{array}$ \\
$\begin{array}{l}\text { Mark must have a distinguishing feature to distinguish sim- } \\
\text { ilar goods from a different company and used in the activi- } \\
\text { ties of trade in goods or services. }\end{array}$ \\
$\begin{array}{l}\text { Mark can be an indication of the origin of goods. } \\
\text { Domain name is a just human-friendly internet }\end{array}$
\end{tabular}
address.

Source: Processed by the author, $2020^{29}$

From the table above, we can see the differences between a domain name and a mark. There are differences between both of them. A domain name is different with a mark and based on the definition in Indonesia Trademark Law, also can be noted that in Law of Republic Indonesia Number 20 of 2001 there is no regulation regarding the domain name. Therefore, in the case of Mustikaratu.com, the police officer can not apply trademark law to Tjandra Sugiono because substantially domain name is different from a mark. Domain name is not a sign.

There are several differences between domain names and trademarks. This article is to analyse whether the Indonesia Trademark Law is in accordance with the legal basis of answering a variety of domain names or not. In order to see that, it is necessary to describe whether the domain is a "sign" in accordance with those in the Trademark Law or not. So, there must be a breakdown between the difference of it in order to conclude that the Trademark Law is suitable, so it can be concluded from the differences that the domain name, cannot be categorised as Marks.

A significant difference is that several holders of rights may have the right to use the same trademark. The trademark is a distinctive sign for specific groups of goods and services, and other holders of rights may register an identical trademark for other types of goods and services. Another difference is that in principle, the holder owns the trademark rights for an indefinite period. Trademark registration can be renewed every 10th year an unlimited number of times. The right to a registered trademark may lapse if it is not used, but the owner does not lose the trademark if the registration fee has been paid and no objections to the registration are submitted. Besides, protection is geographically limited to countries where the trademark has been registered or area where its usage established trademark. ${ }^{30}$

However, sometimes domain name can be a trademark if the owner of the trademark registers his trademark to a registrar (like PANDI or Very Sign). Then, his trademark cannot be registered by other people because the principle of registering a domain name is "first come first served".

Indonesia trademark law (Law Number 20 of 2016) can be applied in domain name dispute if the all of terms and conditions regarding cancellation

29 Cita Citrawinda Priapantja, 2000, Keberlakuan Hak Atas Kekayaan Intelektual (HAKI) dalam Suatu Sistem Informasi dan Jaringan Informasi, Student Paper, Pendidikan Lanjutan Ilmu Hukum Mengenai Hukum Teknologi Informasi dan Telekomunikasi Studi Kasus Penerapan E-Commerce, Jakarta, pp. 10-11.

30 Kari Anne Lang-Ree, 2010, "Some Comments on The Relationship Between Trademark Law and Domain Names Within The No Domain", Journal Nordiskt Immateriellt Rättsskydd, No. 6. 
and transfer domain name can be fulfilled. In order to apply cancellation tort of a domain name, it must be fulfilled this terms and conditions: ${ }^{31}$ a) There is evidence from the complainant that he has the legal rights of the mark, through registration or first use. It depends on the law system in where the complainant will be submitted, and the date of registration or the use of the mark in that country must be the firstly from the date of respondent's domain name registration. b) Domain name, as the object of dispute, must have an identicality or similarity to the mark from the compliant. c) With no rights and legitimate, the respondent not only has been registered the domain name but also is being used for the trade-in similar goods or services. (for the well-known mark the part of similar goods or service can be ignored). d)The respondent has been registered and is being used the domain name in bad faith.

A domain name can be a trademark, or it can not be a trademark. In order to protect domain names and to ensure that a domain name does not duplicate another, domain names are registered.

If a company or individual is using a registered domain name, can it also be registered as a trademark? Yes. First, the prospective trademark has to consist of only the domain name and not the entire uniform resource locator (URL). Second, the domain name has to be used to identify goods and services and not only act as an address to an internet site. Amazon.com is one of the examples. Amazon.com is not only the address of the internet site but is a symbol of the various goods and services sold on the site. Amazon.com is the name of a company that operates an internet site and the name which its stock is traded. In order to register a domain name as a trademark, it has first to be registered by ICANN as a domain name.
Then the domain name has to act as an identifier or goods and services and not only act as part of a URL. From there on, the registration process is the same as for any other trademark. ${ }^{32}$

To get the mark's rights and legitimacy, the registrant (domain name holder) must apply mark registration to Indonesia Directorate General of Intellectual Property Rights (Dirjen HKI). Application of registration of a mark can be rejected if $: 33$

a. contrary to state ideology, regulations legislation, morality, religion, morality, or public order

b. $\quad$ same as, relating to, or just mentioning goods and or services requested for registration.

c. contains elements that can mislead the public about the origin, quality, type, size, type, purpose the use of goods and or services requested registration or is the name of a plant variety protected for similar goods and or services;

d. contains information that is not in accordance with the quality, benefits, or efficacy of goods and or services produced; Is similar in its essential part or its entirety with a well-known mark owned by another party for the same kind of goods and/or services

e. does not have distinguishing features; and/or

f. is a common name and/or public property symbol.

In registering a mark, there is a classification of goods or services. WIPO called nice classification. ${ }^{34}$ If a domain name's holder wants to register his domain name as a mark, the officer in Indonesian Directorate General of Intellectual Property Rights will check the classification of the domain name in nice classification.

An agreement established the International Classification of Goods and Services for the

\footnotetext{
J.B. Lumenta, 2001, Sistem Perlindungan HKI di Dunia Cyber, Ministry of Research and Technology, Jakarta, p. 4.

Timothy Lee Wherry, 2009, Intellectual Property Everything The Digital-Age Librarian Needs to Know, Indiana Publishing House, New Delhi, pp. 85-86

3 See Article 20 of Law of Republic Indonesia No. 20 of 2016 regarding Mark and Geographic Indication (State Gazzette of the Republic of Indonesia No. 252 of 2016 and Additional State Gazzette of the Republic of Indonesia No. 5953 of 2016).

34 World Intellectual Property Organization, "Nice Classification", http://www.wipo.int/classifications/nice/en/.
} 
Purposes of the Registration of Marks concluded at the Nice Diplomatic Conference, on June 15, 1957, was revised at Stockholm, in 1967, and at Geneva, in 1977, and was amended in 1979. The countries party to the Nice Agreement constitute a Special Union within the framework of the Paris Union for the Protection of Industrial Property. They have adopted and apply the Nice Classification for the registration of marks. Each country as parties to Nice Agreement is obliged to apply Nice Classification for marks registration ${ }^{35}$, either as principal classification or as subsidiary classification. They also have to include official documents and publications related to registrations of marks, numbers of the classes of the Classification to which the goods or services which the marks registered belong. ${ }^{36}$

Use of the Nice Classification is mandatory not only for the national registration of marks in countries party to the Nice Agreement but also for the international registration of marks effected by the International Bureau of WIPO, the African Intellectual Property Organization (OAPI), the African Regional Intellectual Property Organization (ARIPO), the Benelux Organisation for Intellectual Property (BOIP) and the European Union Office for Harmonisation in the Internal Market (Trade Marks and Designs) (OHIM). The Nice Classification is also applied in several countries who are not a party to the Nice Agreement. ${ }^{37}$ Domain name must be in one of the lists of nice classification. In Nice Agreement domain name can be classified as a service mark in class number 38 and/or 42 .

Until now, there is still a debate regarding the domain name as a mark. Benjamin Wright said that "The commercialisation of the Internet has made ownership of a domain name related to an established trademark a valueable asset. However, the relationship between domain name, which in and address, and trademark is not always clear". ${ }^{38}$

However, the dispute resolution needs the new procedural code because the domain name is not entirely the same with mark. The judges are required to make a new finding in law (rechtsvinding) with making grammatical interpretation and teleological or sociological on several provisions in trademark law, such as about the definition and the scope of mark, good faith principle, and the civil tort while waiting for the revision of trademark law. ${ }^{39}$

\section{Domain Name Dispute}

Today, on 5th February 2018, PANDI regulated the Regulation No 005/K/DNP/Domain Name Dispute Resolution/II/2018/PANDI-Public (PANDI Dispute Resolution Regulation) ${ }^{40}$ to solve the domain name dispute and set up PPND. ${ }^{41}$

The establishment of Domain Name Dispute Settlement (PPND) is an embodiment of one of the authorities granted legislation to Indonesian Internet Domain Name Managers (PANDI). Article 75 Paragraph (3) PP No. 82 of 2012 concerning the Implementation of Electronic Transactions and Systems regulates that PANDI, as the Indonesian internet domain name registry has one function to resolve domain name disputes.

PPND is the path to resolving nonlitigation disputes over disputes over rights to an Indonesian internet domain name. Legal sources for implementing PPND can be found in the PPND Policy.

\footnotetext{
World Intellectual Property Organization (WIPO), https://www.wipo.int/classifications/nice/en/preface.html, accesed on 28th September 2020 at 08:22 PM

3 World Intellectual Property Organization (WIPO), https://www.wipo.int/classifications/nice/en/preface.html, accesed on 28th September 2020 at 08:24 PM

Ibid.

Benjamin Wright and Jane K. Winn, 2000, The Law of Electronic Commerce Third Edition, Aspen Law and Business, New York, pp. 16-21. Sabartua Tampubolon, 2013, Aspek Hukum Nama Domain di Internet dan Pengaturannya di Indonesia, Kepel Press, Yogyakarta, pp. 90-91.

Pengelola Nama Domain Internet Indonesia, 2018, Domain Name Dispute Resolution Policy, Policy Brief, Pengelola Nama Domain Internet Indonesia, Jakarta.

41 Indonesia term for Domain Name Dispute Resolution
} 
PPND handles three types of domain name disputes, namely trademark-related domain name disputes, domain name disputes related to registered names and domain name disputes related to propriety applicable in the community.

In Article 1.11 "Domain Name Dispute" means others are violating a state of a party's rights about a registered Domain Name excluding disputes over content and/or supervision over the Domain Name. Internet Domain Name Resolution Dispute principle prioritises a concord dispute resolution between the deviated Parties through mediation unless the Parties remain in their own opinion. The investigation of the disputed matter then would be fully authorised by PPND. ${ }^{42}$ Panel set out under the policy. ${ }^{43}$

Therefore in this part, the author would like to explain the obstacles of law enforcement on domain name dispute in Indonesia. The author wants to reveal some of the facts in Indonesia regarding the domain name dispute.

Like other states which have adopted the development of information technology for their economy, Indonesia also has many technological advances also utilise this information. However, development of this technology has not been accompanied by the preparation of cyber law and law enforcement that provides legal certainty for the community.

Even though Indonesia has enacted a law regarding electronic information which includes set up a domain name problem, but law enforcement related to a domain name is still experiencing many obstacles, because the arrangement is still possible emergence of different interpretations within the society.

Besides, the law does not specifically regulate legal issues this domain name. Law enforcement is also stymied because law enforcement officers are also law officers that are still stuttering due to much technology. This condition is not limited only to judges, prosecutors, police, and bureaucracy who are often hindered in its ability improvement, but also the lawyers. An unprepared lawyer who anticipates in the information technology development makes the case in this area are still dormant. The Indonesia infrastructure of Internet Server strongly influenced this law. However, there are still not covered by the Internet yet.

Therefore, it can be said that the lack of infrastructure is an obstacle in the information technology-related law enforcement with internet access is still difficult for law enforcement because of the limited tools available.

Legal awareness of Internet users based on the ethic that characterises the utilisation of information technology is also an obstacle for law enforcement related to a domain name. As a new problem, it is clear not to grow a new awareness among the public to utilise this progress by continuing to respect other people's property is legally recognised. Besides all of the obstacles in domain name's enforcement can be better resolved.

\section{Trademark Infringement}

WIPO defines a trademark as any sign that individualises the goods of the given enterprise and distinguishes them from the goods of its competitors. This definition comprises of two aspects, sometimes referred to as different functions of trademarks, however, interdependent and for all practical purposes should always be looked at together.

In order to individualise a product for the consumer, the trademarks must indicate its source. This condition does not mean that it must inform the consumer of the actual person who has manufactured the product. The origin function is to distinguish that goods of the given enterprise from those of other enterprises. ${ }^{44}$

\footnotetext{
Penyelesaian Perselisihan Nama Domain, "Kebijakan PPND”, https://ppnd.pandi.id/, accessed on 21 th April 2014.

Article 4.4 of Pengelola Nama Domain Internet Indonesia Dispute Resolution Regulation.

World Intellectual Property Organization, 1997, Introduction to Intellectual Property Theory and Practice, Kluwer Law International, Alphen aan den Rijn, p. 184.
} 
Because of the function of trademarks, trademarks need to be protected. The protection of trademarks only is done after the trademarks are already registered based on the Paris Convention. There are two principles when registering intellectual property rights. They are first to use and first to file, and for the registration of trademarks, the principle is first to file. Trademarks Law is also enacted to protect in infringement trademarks.

In countries that have traditionally based trademark protection on use, the registration of a trademark merely confirms the trademarks right that has been acquired by use. Consequently, the first user has priority in a trademarks dispute, not the one who registered first the trademarks. This approach has been chosen by the United States of America, the Philippines, Indonesia and all countries with systems of law on the traditional British model. Furthermore, the user has a significant bearing on many other aspects of the registration procedure and also on the defence of a registered trademark. ${ }^{45}$

With the ease of domain name registration system by anyone and anywhere, as well as the lack of response factors, most business people who already had a well-known mark through its products, registration of a domain name is often misused by certain parties to gain profit by listing famous or popular names in the community. The goal is to sell it back to the other interested parties on behalf of a price above the price of registration. The action is an action for profit by using other people's brands, in the internet world and the so-called cybersquatting culprit is called cybersquatter. ${ }^{46}$

In the global trade era, and in line with international conventions that have been ratified by Indonesia, the Republic of Indonesia enacted a law regarding trademarks. Historically, laws and regulations in the field of intellectual property rights in Indonesia has been since 1840. Dutch colonial government introduced the first legislation regarding the protection of intellectual property rights in 1844. Indonesia, which at the time still called the Netherlands East-Indies, has been a member of Paris Convention for the protection of industrial property since 1888 and a member of the Berne Convention for the protection of literary and artistic works since 1914. On 11th October 1961, the Indonesian government enacted law number 21 of 1961 regarding trademarks to replace the Dutch colonial. The Trademarks Law 1961 was the first Indonesian law in the field of intellectual property rights. This act established to protect the public from imitation goods or pirated. ${ }^{47}$ Indonesia Trademark Law that comes into force is Law No 20 of 2016 concerning Mark and Indication Geographical as has been described above that the principle of registration trademarks in Indonesia is first to file. Hence, to get the full protection from the state, the owner from the trademarks must register the trademarks to Indonesia's Intellectual Property (IP) office (Direktorat Jenderal Hak Kekayaan Intelektual) first. So, only the owner of registered trademarks has the exclusive right.

Domain names are by character quite similar to trademarks since they serve as source indicators; trademark is worldwide. It is therefore very difficult to impose trademarks legislation on domain names despite their common features.

Imposing Trademark legislation in cases of trademark infringement on the Internet, where third parties register and use existing trademarks as domain names, has also faced some challenges. However, the protection of the domain names under the trademark legislation as trademarks seems to be even more difficult, in particular in jurisdictions that do not recognise unregistered trademarks. ${ }^{48}$

45 International Bureau of WIPO, 1993, Introduction to Trademark Law \& Practice (second edition), WIPO Publication. No. 653.

46 Rizayusmanda, "Analisa Persfektif Yuridis Tentang Nama Domain (domain name) Berdasarkan Undang-Undang Nomor 15 Tahun 2001 Tentang Merek”, Journal SOLUSI, Vol. 4, No. 1, Januari, 2014, p. 127.

47 Direktorat Jenderal Hak Kekayaan Intelektual Kementrian Hukum dan Hak Asasi Manusia Republik Indonesia <https://dgip.go.id/sejarahperkembangan-perlindungan-kekayaan-intelektual-ki> viewed on Monday, 28th September 2020 at 08:12 PM

48 Ana Rac`ki Marinkovic, "Domain names: towards a new form of IP Right", Journal of Intellectual Property Law \& Practice, Vol. 6, No. 9, 2011, Oxford University Press, Oxford. 
Some argue that use of a trademark as part of a domain name should receive the same stringent protection as other types of use. Others argue that traditional trademark law cannot be applied to the new technology of the Internet.

There are inherent difficulties that arise when a court attempts to apply trademark law to domain name disputes. It is impossible to completely separate trademarks from domain names. The inevitable commingling of these two spheres requires a reconciliation between the registration procedures for trademarks and domain names. There is no definitive resolution to a conflict which results when a party registers another party's trademark as a domain name. However, a body of case law is developing that will protect trademark owners, similar to that which exists regarding other types of trademark actions. Despite any differences in methodology, the courts have consistently endeavoured to prevent a defendant from profiting by his acts of bad faith. ${ }^{49}$

\section{Conclusion}

A domain name is different from a mark. Therefore in the case of Mustika Ratu, the police officer was not using trademark law to resolve the dispute. There is no regulation regarding domain name in the law of Republic Indonesia Number 15 of 2001 regarding trademark. Substantially, Indonesia Trademark Law is not suitable to resolve domain name dispute because a domain name is not the subject of matter in Law of Republic Indonesia Number 20 of 2016 regarding Mark and Geographic Indication. In order to resolve domain name dispute using trademark law, the Law of Republik Indonesia Number 20 of 2016 then needs an amendment. The law needs to regulate domain name specifically. Because domain name is not a sign, it is an internet address.

Indonesia Trademark law needs an amendment. The Trademark Law needs to regulate directly regarding domain name. It is essential to set up regarding the definition of domain name as part of mark. It needs to make a new legal decision in domain name dispute. The judges and also the law officer need to upgrade their ability in domain name. Start from February 5 2018, one of the best choices in solving the domain name dispute is through non-litigation resolution through PPND.

\section{BIBLIOGRAPHY}

\section{A. Books}

Cambell, Dennis and Champbell, Christian, 1998, Law of International Online Business A Global Perspective, Sweet \& Maxwell, London.

Creech, Kenneth, 2000, Electronic Media Law and Regulation Third edition, ButterworthHeinemann, Oxford.

Fitzgerald, Brian, et.al, 2011, Internet and E-commerce Law, Business and Policy, Thomson Reuters (Professional), Sydney.

International Bureau of WIPO, 1993, Introduction to Trademark Law \& Practice (second edition), WIPO Publication. No. 653.

Lumenta, J.B., 2001, Sistem Perlindungan HKI di Dunia Cyber, Ministry of Research and Technology, Jakarta.

Ningsih, Ayup Suran, 2019, Hukum Persaingan Usaha dan Geliat UMKM, Fastindo, Semarang.

Reed, Chris, 2004, Internet law: text and materials, Cambridge University Press, Cambridge.

Rosenoer, Jonathan, 1997, Cyber Law The Law of The Internet, Springer, New York.

Siburian, Paustinus, 2004, Arbitrase Online, Djambatan, Jakarta.

\footnotetext{
49 Jonathan Rosenoer, 1997, Cyber Law The Law of The Internet, Springer, New York, p. 95.
} 
Smedinghoff, Thomas J, 2000, Online Law TheSPA's Legal Guide to doing Business on The Internet, Addison Wisley, Boston.

Tampubolon, Sabartua, 2013, Aspek Hukum Nama Domain di Internet dan Pengaturannya di Indonesia, Kepel Press, Yogyakarta.

Wherry, Timothy Lee, 2009, Intellectual Property Everything The Digital-Age Librarian Needs to Know, Indiana Publishing House, New Delhi.

World Intellectual Property Organization, 1997, Introduction to Intellectual Property Theory and Practice, Kluwer Law International, Alphen aan den Rijn.

Wright, Benjamin and Winn, Jane K., 2000, The Law of Electronic Commerce Third Edition, Aspen Law and Business, New York.

\section{B. Article Journals}

Lang-Ree, Kari Anne, 2010, "Some Comments on The Relationship Between Trademark Law And Domain Names Within The No Domain", Journal Nordiskt Immateriellt Rättsskydd, No. 6.

Marinkovic, Ana Racki, "Domain names: towards a new form of IP Right", Journal of Intellectual Property Law \& Practice, Vol. 6, No. 9, 2011, Oxford University Press, Oxford.

Ningsih, Ayup Suran, "Implikasi Undang-Undang Nomor 5 Tahun 1999 tentang Larangan Praktek Monopoli dan Persaingan Usaha Tidak Sehat pada Pelaku Usaha Mikro Kecil dan Menengah (UMKM)." Jurnal Penelitian Hukum De Jure 19, No. 2, 2019.

, "License Revocation of Insurance Companies and Legal Protections of the Policyholders", Jurnal Hukum Novelty, 11(1), 2020.

Ningsih, Ayup Suran, Waspiah Waspiah, and Selfira Salsabilla. "Indikasi Geografis atas Carica Dieng sebagai Strategi Penguatan Ekonomi Daerah.” Jurnal Suara Hukum 1.1 (2019): 105-120.
Ningsih, Ayup Suran, and Balqis Hediyati Maharani. "Penegakan Hukum Hak Cipta Terhadap Pembajakan Film Secara Daring." MetaYuridis 2.1 (2019).

Rizayusmanda, "Analisa Persfektif Yuridis Tentang Nama Domain (domain name) Berdasarkan Undang-Undang Nomor 15 Tahun 2001 Tentang Merek", Journal SOLUSI, Vol. 4, No. 1, Januari, 2014.

\section{Researches}

Pengelola Nama Domain Internet Indonesia, 2018, Domain Name Dispute Resolution Policy, Policy Brief, Pengelola Nama Domain Internet Indonesia, Jakarta.

Priapantja, Cita Citrawinda, 2000, Keberlakuan Hak Atas Kekayaan Intelektual (HAKI) dalam Suatu Sistem Informasi dan Jaringan Informasi, Student Paper, Pendidikan Lanjutan Ilmu Hukum Mengenai Hukum Teknologi Informasi dan Telekomunikasi Studi Kasus Penerapan E-Commerce, Jakarta.

\section{Internet}

Direktorat Jenderal Hak Kekayaan Intelektual Kementrian Hukum dan Hak Asasi Manusia Republik Indonesia <https://dgip.go.id/ sejarah-perkembangan-perlindungankekayaan-intelektual-ki> viewed on Monday, 28th September 2020 at 08:12 PM

Internet Assigned Numbers Authority, "Root Zone

Database", http://www.iana.org/domains/ root/db, accessed on 28th April 2018.

Internet Corporation for Assigned Names and Numbers, "Information for Registrars", http://www.icann.org/en/resources/ registrars, accessed on 1st May 2018. , "Registry Listings", http://www.icann.org/ en/resources/registries/listing, accessed on 28th April 2018.

, http://www.icann.org/, accessed on 1st May

"Domain Name Registration Process", 
http://whois.icann.org/en/domain-nameregistration-process, accessed on 1 st May 2018.

, “About WHOIS”, http://whois.icann.org/ en/about-whois, accessed on 1st May 2018.

Kementerian Hukum dan HAM RI, "Konstruksi Hukum Nama Domain: Sebuah Kepemilikan Atau Lisensi", http://ditjenpp.kemenkumham. go.id/hukum-teknologi/669-konstruksihukum-nama-domain-sebuah-kepemilikanatau-lisensi.html accessed on10th August 2020.

PANDI, https://pandi.id/whois/, accessed on 28th September 2020.

PANDI < https://pandi.id/statistik/> viewed on 26th April 2018 at 23:49 PM.

PANDI https://pandi.id/registrar/ accessed on 28 September 2020 at 7:55 PM.

PANDI https://pandi.id/registrar/ accessed on 28 September 2020 at 7:56 PM

Penyelesaian Perselisihan Nama Domain, "Kebijakan PPND", https://ppnd.pandi.id/, accessed on 21th April 2014. , "Putusan", https://ppnd.pandi.id/putusan/ accessed on 10th August 2020.

World Intellectual Property Organization, "Frequently Asked Question: Internet
Domain Names, http://www.wipo.int/amc/ en/center/faq/domains.html, accessed on 20th April 2019.

World Intellectual Property Organization, "Nice Classification", $\quad$ http://www.wipo.int/ classifications/nice/en/.

World Intellectual Property Organization (WIPO), https://www.wipo.int/classifications/nice/en/ preface.html, accesed on 28th September 2020 at 08:22 PM

World Intellectual Property Organization (WIPO), https://www.wipo.int/classifications/nice/en/ preface.html, accesed on 28th September 2020 at 08:24 PM

\section{E. Legislations}

Law of Republic Indonesia No. 20 of 2016 regarding Mark and Geographic Indication (State Gazzette of the Republic of Indonesia No. 252 of 2016 and Additional State Gazzette of the Republic of Indonesia No. 5953 of 2016).

Pengelola Nama Domain Internet Indonesia Dispute Resolution Regulation.

\section{F. Court Ruling}

The United States Court of Appeals, 2010, 9th Circuit, Office Depot Inc v Zuccarini. 